\title{
Lok Baintan Floating Market: The Ecotourism Potential of Rural Communities
}

\author{
Ersis Warmansyah Abbas ${ }^{1 *}$ Mutiani ${ }^{1}$ Muhammad Rezky Noor Handy ${ }^{1}$ \\ Rizky M. Shaleh ${ }^{1}$ Noorya Tasya Febrylia Witari Hadi ${ }^{1}$

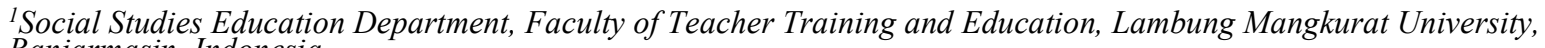 \\ Banjarmasin, Indonesia \\ *Corresponding author. Email: ersiswa@ulm.ac.id
}

\begin{abstract}
The tourism sector demands innovation to continue to be able to attract the attention of tourists. Innovation is not only in the context of improving infrastructure but also changing the mindset of tourist destinations based on environmental beauty. This mindset change is known as the concept of ecotourism. Ecotourism requires the development of local potential as the main attraction as in the Lok Baintan floating market. This article describes the potential of ecotourism in Lok Baintan Village using a qualitative approach with the descriptive method of the Miles and Huberman models. The results of the study illustrate that the Lok Baintan Floating Market was originally a traditional market for the fulfillment of the economic activities of the Lok Baintan Village. However, the Lok Baintan floating market was later developed as a tourist destination. The uniqueness of Lok Floating Market in bringing, bidding, and trading merchandise on a boat that is pedaled by the merchant itself as a tourist attraction as natural and cultural beauty in the Lok Baintan Floating Market. Ecotourism in the Lok Baintan floating market has become the main icon of river tourism attractions since 2016 through the South Kalimantan visit program.
\end{abstract}

Keywords: Tourism, ecotourism, and river tourism.

\section{INTRODUCTION}

Shifts in the view of regional development refer to the orientation of the development of the service sector. Each region is competing to improve the service sector to boost the community's economy. South Kalimantan responded to this view by choosing the tourism service sector as one of 13 development programs in 2016-2021 [1][2][3]. In developing regional tourism, it is necessary to have a unique regional potential to be promoted both locally, nationally, and internationally [4]. For the Provincial Government of South Kalimantan in its combination with the Regency Government and the Municipal Government of South Kalimantan, one of the leading tourism developments in the development of river potential as a tourist destination that has traditionally and naturally developed in Lok Baintan Village which is famous for the Lok Baintan Floating Market.

For the people of the Lok Baintan village, the river is not only a form of the ecosystem but also the identity of community life. Community activities are influenced by the existence of rivers, such as; fulfillment of physiological and social needs [5][6]. Thus, the existence of Lok Baintan village with community activities that look unique from the perspective of modern society makes it interesting and unique as tourism potential.

Therefore, after becoming a tourist destination, Lok Baintan Floating Market became a popular tourist attraction. The Lok Baintan floating market is known as a traditional market for the surrounding community [7]. Because of the uniqueness of the development of ecotourism, it becomes an option based on the objective conditions of the Lok Baintan village.

Ecotourism activities are part of the tourism industry which directly gives everyone access to see, know, and enjoy the natural, intellectual and cultural experiences of the local community. As developed in Yogyakarta, Batu City, to East Nusa Tenggara, the development of ecotourism is carried out to promote tourism objects as well as protect them from natural damage [8][9][10].

The existence of attractions can not only be enjoyed in the short term but on the contrary. The sustainability of the Lok Baintan floating market is an asset for the people of Lok Baintan Village. The Lok Baintan floating market has economic, social and cultural potential. This article aims to describe the potential of the Lok Baintan floating market as a capital for ecotourism development. Ecotourism development in Lok Baintan Village is expected to improve the community's economy, increase the number of tourists visiting South Kalimantan, and increase awareness of maintaining tourist attractions.

\section{RESEARCH METHODS}

A qualitative approach with a descriptive method is used to describe the phenomena regarding community activities in Lok Baintan Floating Market holistically [11]. Data collection techniques include; 1) participatory observation 
involving researchers in the situation of activities in the Lok Baintan floating market, 2) interviews conducted intensively and unstructured to the subjects of the study with interview guidelines that have been prepared [12]. The researcher interviewed Lok Baintan five floating market traders, five tourists, and 3) documentation to complete the secondary data needed for the study presented in the form of photographs [13][14]. Data analysis using the interactive model of Miles and Huberman starts at the stages of reducing, presenting, and verifying the data. Field research was conducted at the Lok Baintan Floating Market, in Lok Baintan Village from November 27 to December 4, 2019. Validity Test the validity of the data by implementing source triangulation and technical triangulation so that the activities in the Lok Baintan Floating Market are explained in-depth and focus on the research problem [15][16].

\section{RESEARCH RESULTS AND DISCUSSION}

Floating Market is a traditional market where seller and buyer activities are carried out on the surface of the river using traditional boats (jukung) [17]. In South Kalimantan, there are three floating markets namely the Muara Kuin Floating Market, Lok Baintan and the Piere Tendean Floating Market. This article describes the Lok Baintan Floating Market activity as the main potential for community ecotourism in Lok Baintan Village, whose activities start at 6:00 to 10:00 pm every day. Before being developed as a tourist destination, Lok Baintan Floating Market was a market for Lok Baintan villagers and its surroundings as a barter market for people's needs. However, currently, transactions in Lok Baintan Floating Market are mostly carried out by tourists. Thus, transactions are carried out with money.

Following the development of South Kalimantan tourism, the South Kalimantan Provincial Government in cooperation with the Banjar District Government has made the Lok Baintan Floating Market a tourist destination, one of 13 priority programs for 2016-2021. This is intended to develop the potential of nature-based tourism. Therefore, the South Kalimantan Provincial Government plans and develops tourist infrastructure, accessibility, and public outreach.

Tourism is interpreted as a trip to entertain outside of daily activities [9]. The concept of tourism continues to develop with a new term known as ecotourism. Ecotourism as a form of tourism that is responsible for the preservation of natural areas [10]. Ecotourism is developed by maintaining the cultural integrity of the community. Within this framework, the development of ecotourism in Lok Baintan Village by making floating market activities a tourist attraction by promoting ecological and social principles.

Floating Market Traders Lok Baintan is dominated by female traders. Based on interviews with traders named Masniah (51 years old), Midah (39 years old) and Sapnah (56 years old) at least $80 \%$ ( 21 from 27 traders) of traders are housewives to earn extra income. The traders paddle their boats back and forth peddling their wares to buyers [7]. Due to natural activities occurring on the water, not a few tourists take the time just to observe and actively participate as buyers in the Lok Baintan floating market [18].

As a tourist destination, Lok Baintan Floating Market is not only attractive because of trading activities on the water (river), but also: 1) the existence of transportation modes and motorized boat drivers (klotok) that are ready to transport several tourists every day, agricultural / plantation products, produce fisheries, to crafts every day. 2) good road accessibility makes it easy to reach the floating market location. So to get to the floating market Lok Baintan can use land transportation modes other than rivers, 3) the readiness of the Lok Baintan village government to support tourism activities by building road facilities from village funds, 4) the tourism office of the Banjar district and South Kalimantan Province that work together to promote activities travel through brochures, social media, websites, to national forums, and 5) The role of social communities, such as; onthel community, nanang galuh convocation, green community, melingai community, and several other communities. The social community helps provide promotions to community members to participate in the Lok Baintan floating market exotic.

In addition to the five components above, Lok Baintan Floating Market has superior tourism products that strengthen its potential as the development of ecotourism. As is known, tourism products are something that is offered to the market in the form of goods or just services. Tourism products affect the decision of tourists to visit a tourist attraction. Therefore, tourism products in the form of tourist attractions must be increased so as not to cause saturation by tourists. Based on the type, tourism products at Lok Baintan are divided into two, namely; total tourism products and special tourism products [7][19][17].

First, the total tourism product at Lok Baintan includes all elements consumed by tourists during their trip. Such tourism products are offered by service providers to be enjoyed by tourists. At Lok Baintan total tourism products are rarely used by tourists unless from abroad. For domestic tourists, they only need transportation to reach the Lok Baintan floating market location. Therefore total tourism products are only given through special offers during annual events.

Second, the special tourism products in the Lok Baintan floating market include all components in total tourism products. Special tourist products are products offered and sold as part of individual tourist offers, such as; transportation, food, to handicrafts. At Lok Baintan Special tourism products include:

a. River transportation (klotok) which functions as the main river transportation for tourists to the Lok Baintan floating market.

b. The plantation products which are the main commodity of trade are traded in the Lok Baintan floating market. The plantation products are traded; madang orange, young mango, banana, banana heart, guava, mangosteen, rambutan, sugar apple, to vegetables.

c. Citizens' fisheries products which are dominated by freshwater fish (river), both private catch and aquaculture; cork fish (haruan), tilapia, papuyu, shrimp, sepat, 
d. Food and beverage specialties from South Kalimantan. The culinary trade comes from the natural resources of Lok Baintan Village. The culinary meant is; Banjar Soto, Satay, Rice pundut, Kokoleh, Putu Mayang, free-range, and others.

e. The handicrafts produced by the community in Lok Baintan Village. The handicrafts that are produced certainly emphasize the expertise, skills, and creativity of the maker. The handicrafts made include; purun hats, baskets (baskets), made with weaving techniques, miniature jukung.

The five special tourism products above generally have a positive impact on the development of the ecotourism community in Lok Baintan Village. The development of Lok Baintan Village ecotourism in the economic sector, such as:

First, additional income for women who sell at Lok Baintan floating market. This is because the commodities sold are bought by tourists who have higher purchasing power compared to the local people. So they can increase the price so that it matches the selling price in general.

Second, increased employment for Klotok drivers who take tourists to the Lok Baintan floating market. The development of land infrastructure has made the klotok drivers experience a decrease in income. The existence of the Lok Baintan floating market provides fresh air for Klotok drivers because the majority of tourists prefer the river transportation mode compared to land.

Third, improving infrastructure for the Lok Baintan Village, especially the land routes and the Lok Baintan floating market docks. Although the popularity of Lok Baintan Village is increasing due to the floating market, the surrounding community requires land routes. For the people of Lok Baintan Village, the land route accelerates the distribution of commodities around the village so that it is easy to obtain and trade in the Lok Baintan floating market. The development of Lok Baintan Village ecotourism in the socio-cultural sector, among others:

First, enhancing the preservation of river-based culture. The community continues to preserve the function of nature (river) in all aspects of life even though it has other influences. The community does not leave basic knowledge of how to use rowing boats (called jukung) in meeting physical and non-physical needs.

Second, opening up insights on cultural and artistic investment. Lok Baintan villagers make river culture a tourist attraction and are commercial. Besides, woven handicrafts that were once wrestled by the people of Lok Baintan Village to make their products can now be sold and become special craft materials.

Third, improving the quality of communication between Lok Baintan Village and tourists using the official language (Indonesian). The Lok Baintan Village community is very attached to the Banjar dialect and vocabulary. The language they use makes it alienated from formal language. However, the existence of a floating market "teaches" the Lok Baintan Village community to have companion language skills that can be understood by tourists namely Indonesian [7].
The ecotourism potential of Lok Baintan Village is strongly influenced by the presence of the Lok Baintan Floating Market. The need for a unique experience makes tourists continue to come to this attraction. Maintaining the continuity of Lok Baintan Floating Pasa is a necessity when developing as a tourist destination is the will of the Provincial Government of South Kalimantan, the Regional Government of Banjar Regency, the Lok Baintan community and the hopes of tourists. Therefore, the improvement of the Lok Baintan floating market is not only meant as an increase in tourism facilities and projects towards ecotourism in a combination of economic, sociocultural, and nature conservation sectors, and still more for the positive benefits for the Lok Baintan villagers.

\section{CONCLUSION}

The Lok Baintan floating market is a traditional market used by the people of Lok Baintan Village to meet their daily needs. Unlike traditional markets, activities are carried out on the river. Initially, before becoming a tourist destination, trading activities at Lok Baintan Teaung Market in buying and selling between traders and buyers were carried out by barter. But after becoming a 2016 tourist destination through the South Kalimantan visit program, it became a combination of bartering (along with traders and buyers) and using money, with tourists. Lok Baintan Floating Market as ecotourism puts forward ecological and social principles. Both principles are supported by five components of tourism activities. The five components produce total tourism products and special tourism products. Both tourism products continue to be developed by stakeholders so that the Floating Market is not only known and blessed by domestic tourists but also foreign tourists as icons of the South Kalimantan river tourist attraction.

\section{REFERENCES}

[1] R. Mantala, "Pengembangan Sistem Informasi Pariwisata Kota Banjarmasin Berbasis Android," At-Tadbir J. Ilm. Manaj., vol. 1, no. 1, 2017.

[2] Y. Anwar, M. A., Noor, G. S., Maulana, A. Z., \& Putryanda, "Strategi Pengembangan Wisata Berbasis Kearifan Lokal di Kalimantan Selatan," J. Kebijak. Pembang., vol. 13, no. 2, 2018.

[3] E. W. Ajidayanti, A., \& Abbas, "Utilization of Tourism Bekantan Mascot as a Learning Resource On Social Studies," Innov. Soc. Stud. J., vol. 1 , no. 1, pp. 78-86, 2019.

[4] M. Riswan, "Problematika Pengembangan Ekonomi Kreatif Dalam Menunjang Sektor Pariwisata Di Kalimantan Selatan," J. Kebijak. Pembang., vol. 13, no. 2, pp. 129-139, 2018.

[5] M. Subiyakto, B., \& Mutiani, "Internalisasi Nilai Pendidikan Melalui Aktivitas Masyarakat Sebagai Sumber Belajar Ilmu Pengetahuan Sosial," Khazanah J. Stud. Islam dan Hum., vol. 17, no. 1, pp. 137-166, 2019. 
[6] M. A. Abbas, E. W., Subiyakto, B., Mutiani, M., Jamaluddin, J., \& Syahrin, Kehidupan Sosial Santri di Bantaran Sungai Kota Martapura Sebagai Sumber Belajar IPS. Banjarmasin: FKIP Universitas Lambung Mangkurat, 2017.

[7] M. Z. Arisanty, D., Normelani, E., Putro, H. P., \& Anis, "The Role of Women in Lok Baintan Floating Market, South Kalimantan:Iimplication for Tourism Development," J. Indones. Tour. Dev. Stud., vol. 5, no. 3, pp. 169-174, 2017.

[8] D. Damiasih, "Pengelolaan Goa Tanding Sebagai Ekowisata Di Kabupaten Gunungkidul Yogyakarta," Kepariwisataan J. Ilm., vol. 11, no. 3, 2017.

[9] O. Sukmana, "Model Pengembangan Lingkungan Kota Ekowisata (Studi di Wilayah Kota Batu)," J. Humanit., vol. 5, no. 1, 2012.

[10] I. B. Amtiran, M. I., \& Suryawan, "Praktik Ekowisata Di Kampung Tradisional Bena, Desa Tiworiwu Kabupaten Ngada, Provinsi Nusa Tenggara Timur," J. Destin. PARIWISATA, vol. 4, no. 2, pp. 100-102, 2016.

[11] Sugiyono, Memahami Penelitian Kualitatif. Bandung: Alfabeta, 2016.
[12] W. L. Neuman, Metodologi Penelitian Sosial: Pendekatan Kualitatif Dan Kuantitatif. Jakarta: PT Indeks, 2015.

[13] B. . Afifudin \& Saebani, Metodologi Penelitian Kualitatif. Bandung: Pustaka Setia, 2012.

[14] I. Gunawan, Metode Penelitian Kualitatif Teori dan Praktik. Jakarta: Bumi Aksara, 2014.

[15] Sugiyono, Metode Penelitian Kuantitatif, Kualitatif, dan $R \& D$. Bandung: Alfabeta CV, 2017.

[16] A. M. Yusuf, Metodologi Penelitian Kuantitatif, Kuaalitatif \& Penelitian Gabungan. Jakarta: Prenadamedia Group, 2017.

[17] M. Z. Arisanty, D., Normelani, E., Putro, H. P., \& Anis, "Local Products of Lok Baintan Floating Market, South Kalimantan Province," IOP Conf. Ser. Earth Environ. Sci., vol. 145, no. 1, p. 012067, 2018.

[18] A. Rahmini, N., Pudjihardjo, M., Hoetoro, A., \& Manzilati, "The role of bonding, bridging and linking at traditional markets in Indonesia: a study at Lok Baintan floating market Banjar Regency South Kalimantan," J. Apllied Econ. Bussiness, vol. 3, no. 3, pp. 76-88, 2015.

[19] E. Normelani, "River, Culture and Tourism in Lok Baintan, South Kalimantan," J. Indones. Tour. Dev. Stud., vol. 4, no. 2, 2016. 